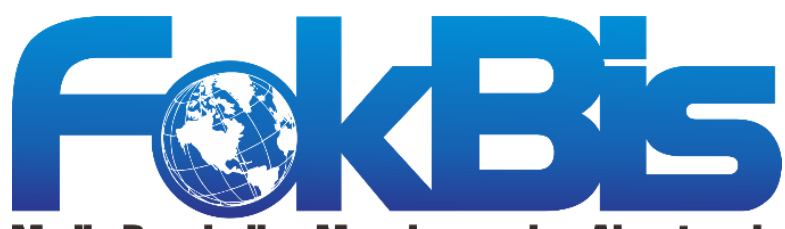

Media Pengkajian Manajemen dan Akuntansi

http://journal.stieputrabangsa.ac.id/index.php/fokbis/index

ISSN: 2623-2480/ P-ISSN: 1693-5209

\title{
Analysis of Market Orientation and Innovation on SMEs Business Performance: Evidance in Kebumen
}

\author{
Ika Susilowati ${ }^{1}$, Eni Kaharti ${ }^{2}$ \\ ${ }^{1,2)}$ Sekolah Tinggi Ilmu Ekonomi Putra Bangsa, Kebumen \\ email: ikasusilowatistiepb@gmail.com
}

\section{Article Information}

\section{History of Article:}

Received: November $11^{\text {th }} 2019$

Accepted: March $3^{\text {rd }} 2020$

Published: July $31^{\text {st }} 2020$

\section{DOI:}

10.32639/fokusbisnis.v19i1.383

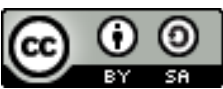

\begin{abstract}
This study aims to analyze empirically the influence of customer orientation, competitor orientation, coordination between functions, innovation on business performance in SMEs in Kebumen. The research data was obtained from SME businesses to scientifically test whether customer orientation, competitor orientation, coordination between functions, innovation affects business performance. The sample used in this study were 100 SMEs in Kebumen Regency who had met the established criteria. The analytical method used is multiple linear regression analysis, using the SPSS 21.0 for windows statistical computer program. The results of hypothesis testing in this study indicate that customer orientation and coordination between functions have a positive effect on business performance. Whereas competitor orientation and innovation have no influence on business performance.
\end{abstract}

Keywords: SMEs; Business Performance; Market Orientation; Innovation

\section{INTRODUCTION}

In the era of increasingly high business competition, every company must be able to anticipate changes and expectations desired by customers for the products produced. According to Bakti \& Harun (2011), there are several solutions used to anticipate such competition, namely competitive strategy, marketing mix, innovation actions and market orientation. Bernardin \& Russel (1993) stated that business performance is the recording of results obtained from all work functions or certain activities during a certain period of time. Ferdinand (2004) also stated that business performance is a factor commonly used to measure the impact of a company's strategy in dealing with competition. In the field of marketing, one way companies do to achieve business performance is to conduct market orientation (Julian, 2010). 
There is a research gap in research that examines the effect of market orientation on business performance. Julian (2010); Castro et al., (2005) proved that market orientation will improve business performance. However, some studies have failed to prove that market orientation will improve business performance (such as Kohli \& Jaworski, 1990; Selnes et al., 1996). With the reason that companies that implement market orientation in addition to increasing value for customers will also increase costs for the company. Like the cost to do marketing research, and pay marketing experts.

Innovation can be used as one of the strategies in achieving business performance (Han et al., 1998). Basically, if a company innovates, the business performance it gets also increases. This statement is supported by Agarwal et al. (2003). In their research, they stated that innovation has an influence on business performance as well as measured by an objective approach and by a subjective approach. But there are studies that give different results. Darroch (2005) in his research stated that innovation does not have an effect on performance either measured by financial or non-financial performance, namely market share and sales growth. He explained that innovations that are not supported by knowledge management will reduce performance.

Keskin (2006) stated three reasons for the need for research on market orientation, innovation and business performance in SMEs with a background in developing countries for the development of science, namely: (1) The majority of research on market orientation is carried out in developed countries such as : United States and United Kingdom. (2) Research on orientation is mostly done on companies with more than 250 employees, whereas market orientation measurements at large periodical companies give different results from SME measurements (3) Empirical research on market orientation on SMEs is still fragmented or not. complete.

Kebumen is a small city that has the biggest coconut sugar income in Java. Even so from an industrial perspective, Kebumen cannot be said to be an industrial or trade city. Because it is rarely found in industrial and commercial activities on a large scale. However, in this city can be found several SMEs that are considered to have great potential to be developed. This has led to increasingly fierce competition among the SME industries in Kebumen.

Based on the results of research that has been described along with research gaps and supporting business phenomena, the researcher will conduct research on the analysis of the influence of market orientation and innovation on business performance in SMEs in Kebumen.

\section{LITERATURE REVIEW}

\section{Small and Medium Enterprises (SMEs)}

Small and Medium Enterprises (SMEs) is a term that refers to the type of small business that has a net worth of at most Rp. 200,000,000 excluding land and buildings where the business is located. And a stand-alone business. The understanding of UKM is based on several regulations including Presidential Decree No. 99 of 1998, Minister of Finance Decree Number 316/ KMK.016/ 1994 dated 27 June 1994, and UU No. 20 of 2008.

\section{Business Performance}

Business performance can be seen as a concept that is used to measure the extent to which market achievements have been achieved by a product produced by the company. Ferdinand (2004) stated that business performance is a factor that is often used to measure the impact of strategies implemented by companies. The company's strategy is always directed to produce good business performance (such as sales volume and sales growth rates) and also good financial performance. Pelham (1997) argued that 
business performance is influenced by three things: firm effectiveness (growth effectiveness), growth/ portion (profit share) and profitability.

Based on previous studies, in general the size of a company's business performance is measured through the value of the sales rupiah, Return on Investment, Return on Assets. However, these measures are seen as aggregative measures produced through accounting and financial processes, but do not directly describe management activities, especially marketing management (Sismanto, 2006). Therefore the measure that should be used is a measurement that can explain the marketing activities. For example, it is better to use a measure of the number of units sold or generated than using only the rupiah value of sales (Putranto, 2003).

\section{Market Orientation}

According to Kohlil \& Jawroski (1990) market orientation is based on certain considerations which classify that the concept is not responsible for the attention of the marketing function, but all departments participate in the collection, distribution and follow-up of market intelligence (Tjiptono et al., 2008: 85) so that market orientation is focused in a market that includes customers and the factors or forces that influence it. To understand the concept of marketing orientation, the three components of behavior in market orientation are: customer orientation, competitor orientation and coordination between functions need to be understood as an inseparable set of circuits.

According to Despande et al. (1993) customer orientation is the highest priority in terms of providing superior values to customers in research conducted by assuming customer orientation is the most fundamental thing for companies. The customer is the most important side of the company to determine the customer orientation (Tjiptono et al., 2008: 91). Customer orientation requires a seller to understand the overall value chain of a buyer. Through customer orientation, companies have the opportunity to form customer perceptions of perceived values which in turn will result in customer satisfaction (Tjiptono et al., 2008: 92). In principle, customer orientation and competitor orientation are two dimensions that are interrelated, inseparable and constitute a unity in the concept of market orientation. Customer orientation and orientation to the piang will provide a different dimension so that the company will be able to increase what is needed by customers and what is our competitor. Customer orientation is often not able to be used as a strategy to win business competition, because companies tend to be only reactive to business problems that arise and do not develop a proactive attitude in outperforming business competitors. Because it needs balance in carrying out these two orientations so that on one hand it is able to win the competition and on the other hand it still satisfies the customer. If the company only emphasizes on one focus exclusively on competition, this action can lead to the neglect of the customer's interests. For this reason, a balanced mix of customer orientation and competitor orientation is proposed as a condition for maintaining competitive advantage.

Coordination between functions is a third aspect component of the market orientation behavior component identified by Slater \& Narver (1990). Coordination between these functions becomes very important for the survival of companies that want to provide satisfaction to customers while winning competition by optimizing the functions in the company carefully. This step is at the same time the company's ability to capture feedback from customers, respond and provide more excellent service in the future (Kohli \& Jaworski, 1990: 64).

\section{Product Innovation}

The definition of product innovation according to Crawford \& Benedetto (2008), is "Innovation that is used in the overall operation of a company where a new product is created and marketed, including innovation in all functional processes / uses." Hurley \& Hult (1998) define innovation as a corporate 
mechanism to adapt in a dynamic environment, therefore companies are required to be able to create new thoughts, new ideas and offer innovative products and improved services that satisfy customers. Often people think that by innovating on something, someone has made positive changes that lead to progress. That opinion is true, but the change (in any form) is for some consumers something that is difficult to take for granted.

Based on the above definition of product innovation, the writer draws the conclusion that what is meant by product innovation is: "An attempt by a company to create new products that aim to adjust to consumer tastes and can increase sales." Thus it can be said that the increasing number of goods offered to consumers and supported by the flow of information about products that are easily obtained, causes them to be more selective in buying an item, both in quality, design style, color and price.

This study examines five variables, namely four independent variables and one dependent variable. The independent variables in this study are customer orientation, competitor orientation, coordination between functions and innovation. The dependent variable in this study is business performance.

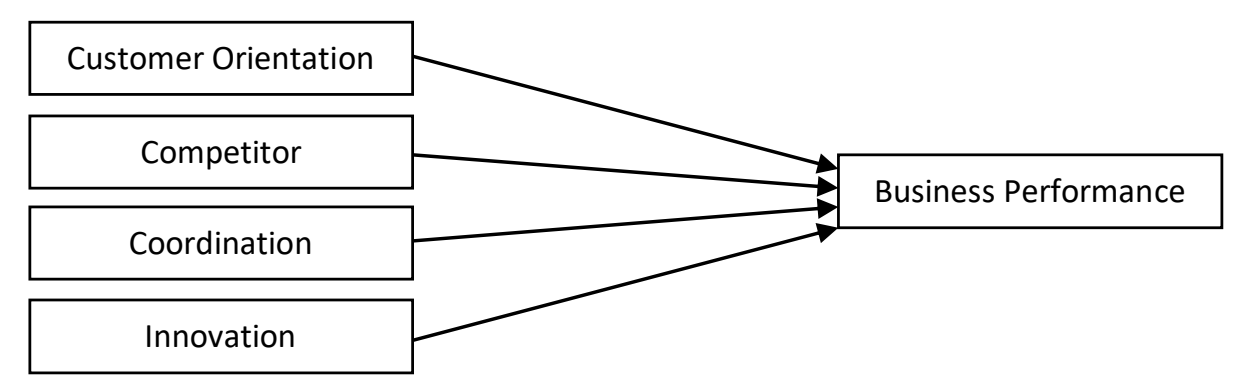

Figure 1. Research Model

The hypothesis proposed in this study is as follows:

H1: Customer orientation has a positive effect on business performance.

H2: Competitor orientation has a positive effect on business performance.

H3: Coordination between functions has a positive effect on business performance.

H4: Innovation has a positive effect on business performance.

\section{RESEARCH METHOD}

\section{Population/ Research Samples}

The population in this study were all SMEs in Kebumen. Samples are businesses that have a workforce of more than ten people. Furthermore, the sampling technique that is also used is purposive sampling technique that is deliberate sampling. That is, researchers determine their own samples taken because there are certain considerations. (Sugiyono, 2009). The number of samples is determined by the characteristics of a workforce of more than 10 people as many as 100 business units. Of the 125 instruments distributed, 100 can be used for analysis. 


\section{Procedures}

The data used in this study are primary data obtained by distributing research instruments to the respondents. The dissemination of research instruments is carried out by way of researchers coming directly to each UKM to collect data, by asking permission from the SME owner in advance

\section{Data, Instruments and Data Collection Techniques}

The data in this study are primary data obtained directly from respondents through the dissemination of instruments. The instrument used in this study was a questionnaire with a Likert scale 7. The sampling technique that was also used was the purposive sampling technique, which was intentional sampling. That is, researchers determine their own samples taken because there are certain considerations. (Sugiyono, 2009). The number of samples is determined by the characteristics of a workforce of more than 10 people as many as 100 business units.

\section{Data Analysis Technique}

The analytical method used is multiple linear regression analysis, using the SPSS 21.0 for windows statistical computer program. Before testing multiple linear regression analysis of the research hypothesis, first testing the classical assumptions of the data will be processed through the normality test if it has a significance value $>0.05$. Multicollinearity test by looking at the VIF value of each independent variable, if the VIF value $<10$. Heteroscedasticity test uses plot graphs between the predicted values of the dependent variable ZPRED and the residual SRESID. Next test the hypothesis to determine the effect of several independent variables $(\mathrm{X})$ on the dependent variable $(\mathrm{Y})$. Multiple linear analysis is performed by the coefficient of determination test, $\mathrm{t}$ test, and $\mathrm{F}$ test.

\section{Demographics of Respondents}

Table 1. Overview of Respondents Based on Length of Business

\begin{tabular}{|c|c|c|c|c|c|}
\hline & & Frequency & Percent & Valid Percent & Cumulative Percent \\
\hline & 10 & 2 & 2.0 & 2.0 & 2.0 \\
\hline & 11 & 4 & 4.0 & 4.0 & 6.0 \\
\hline & 12 & 6 & 6.0 & 6.0 & 12.0 \\
\hline & 13 & 1 & 1.0 & 1.0 & 13.0 \\
\hline & 14 & 3 & 3.0 & 3.0 & 16.0 \\
\hline & 15 & 5 & 5.0 & 5.0 & 21.0 \\
\hline & 16 & 3 & 3.0 & 3.0 & 24.0 \\
\hline & 17 & 2 & 2.0 & 2.0 & 26.0 \\
\hline & 19 & 1 & 1.0 & 1.0 & 27.0 \\
\hline & 2 & 1 & 1.0 & 1.0 & 28.0 \\
\hline Valid & 20 & 4 & 4.0 & 4.0 & 32.0 \\
\hline vallu & 21 & 2 & 2.0 & 2.0 & 34.0 \\
\hline & 22 & 1 & 1.0 & 1.0 & 35.0 \\
\hline & 23 & 4 & 4.0 & 4.0 & 39.0 \\
\hline & 24 & 1 & 1.0 & 1.0 & 40.0 \\
\hline & 25 & 2 & 2.0 & 2.0 & 42.0 \\
\hline & 26 & 2 & 2.0 & 2.0 & 44.0 \\
\hline & 28 & 2 & 2.0 & 2.0 & 46.0 \\
\hline & 29 & 2 & 2.0 & 2.0 & 48.0 \\
\hline & 3 & 3 & 3.0 & 3.0 & 51.0 \\
\hline & 30 & 1 & 1.0 & 1.0 & 52.0 \\
\hline & 31 & 1 & 1.0 & 1.0 & 53.0 \\
\hline
\end{tabular}




\begin{tabular}{ccccc}
33 & 1 & 1.0 & 1.0 & 54.0 \\
34 & 1 & 1.0 & 1.0 & 55.0 \\
4 & 6 & 6.0 & 6.0 & 61.0 \\
40 & 1 & 1.0 & 1.0 & 62.0 \\
5 & 9 & 9.0 & 9.0 & 71.0 \\
6 & 11 & 11.0 & 11.0 & 82.0 \\
7 & 1 & 1.0 & 1.0 & 83.0 \\
8 & 10 & 10.0 & 10.0 & 93.0 \\
9 & 7 & 7.0 & 7.0 & 100.0 \\
\hline Total & 100 & 100.0 & 100.0 & \\
\hline
\end{tabular}

Source: Data Processed, 2019

General description of respondents based on length of business from table 1 shows that MSMEs in Kebumen with 6 years and 8 years of business dominate more.

\section{Validity Test}

Table 2. Validity Test

\begin{tabular}{|c|c|c|c|c|}
\hline Variables & Indicator & Pearson Correlation & P-Value & Result \\
\hline \multirow{8}{*}{ Customer Orientation } & X1_1 & 0,835 & $>0,50$ & Valid \\
\hline & X1_2 & 0,929 & $>0,50$ & Valid \\
\hline & X1_3 & 0,937 & $>0,50$ & Valid \\
\hline & X1_4 & 0,872 & $>0,50$ & Valid \\
\hline & X1_5 & 0,848 & $>0,50$ & Valid \\
\hline & X1_6 & 0,905 & $>0,50$ & Valid \\
\hline & X1_7 & 0,875 & $>0,50$ & Valid \\
\hline & X1_8 & 0,867 & $>0,50$ & Valid \\
\hline \multirow{5}{*}{$\begin{array}{l}\text { Competitor } \\
\text { Orientation }\end{array}$} & $X 2 \_1$ & 0,722 & $>0,50$ & Valid \\
\hline & $x 2 \_2$ & 0,759 & $>0,50$ & Valid \\
\hline & $x 2 \_3$ & 0,746 & $>0,50$ & Valid \\
\hline & $X 2 \_4$ & 0,784 & $>0,50$ & Valid \\
\hline & $X 2 \_5$ & 0,739 & $>0,50$ & Valid \\
\hline \multirow{5}{*}{ Coordination } & X3_1 & 0,882 & $>0,50$ & Valid \\
\hline & X3_2 & 0,860 & $>0,50$ & Valid \\
\hline & X3_3 & 0,888 & $>0,50$ & Valid \\
\hline & X3_4 & 0,881 & $>0,50$ & Valid \\
\hline & X3_5 & 0,819 & $>0,50$ & Valid \\
\hline \multirow{3}{*}{ Innovation } & X4_1 & 0,735 & $>0,50$ & Valid \\
\hline & X4_2 & 0,885 & $>0,50$ & Valid \\
\hline & X4_3 & 0,888 & $>0,50$ & Valid \\
\hline
\end{tabular}




\begin{tabular}{ccccc} 
& X4_4 & 0,845 & $>0,50$ & Valid \\
X4_5 & 0,644 & $>0,50$ & Valid \\
& X4_6 & 0,819 & $>0,50$ & Valid \\
\hline Y_1 & 0,760 & $>0,50$ & Valid \\
Business & Y_2 & 0,862 & $>0,50$ & Valid \\
Performance & Y_3 & 0,742 & $>0,50$ & Valid \\
& Y_4 & 0,865 & $>0,50$ & Valid \\
& Y_5 & 0,820 & $>0,50$ & Valid \\
& Y_6 & 0,789 & $>0,50$ & Valid
\end{tabular}

Source: Data Processed, 2019

\section{Reliability Test}

Table 3. Reliability Test

\begin{tabular}{cccc}
\hline Variables & Cronbach's Alpha & P-Value & Result \\
\hline Customer Orientation & 0,959 & $>0,60$ & Reliable \\
Competitor Orientation & 0,806 & $>0,60$ & Reliable \\
Coordination & 0,915 & $>0,60$ & Reliable \\
Innovation & 0,892 & $>0,60$ & Reliable \\
Business Performance & 0,892 & $>0,60$ & Reliable \\
\hline
\end{tabular}

Source: Data Processed, 2019

\section{Hypotheses Test}

Table 4. Coefficient of determination $\left(R^{2}\right)$

Model Summary

\begin{tabular}{|l|l|l|}
\hline Model & $R$ & R Square \\
\hline 1 & $.765^{\mathrm{a}}$ & .585 \\
\hline
\end{tabular}

a. Predictors: (Constant), TOTAL_X4, TOTAL_X2, TOTAL_X1, TOTAL_X3

b. Dependent Variable: TOTAL_Y

R Square value of 0.585 or $58.5 \%$ of the business performance variable can be explained by the research variables namely customer orientation, competitor orientation, coordination between functions, and innovation. While the rest $(100 \%-58.5 \%)$ of $41.5 \%$ is explained by other variables outside the research model. 
Table 5. $t$-Test

Coefficients $^{\mathrm{a}}$

\begin{tabular}{|c|c|c|c|c|c|}
\hline \multirow[t]{2}{*}{ Model } & \multicolumn{2}{|c|}{ Unstandardized Coefficients } & \multirow{2}{*}{\begin{tabular}{|l|}
$\begin{array}{l}\text { Standardized } \\
\text { Coefficients }\end{array}$ \\
Beta
\end{tabular}} & \multirow[t]{2}{*}{$\mathrm{T}$} & \multirow[t]{2}{*}{ Sig. } \\
\hline & B & Std. Error & & & \\
\hline \multirow[t]{9}{*}{$\begin{array}{l}\text { (Consta } \\
\text { nt) }\end{array}$} & 9.346 & 2.505 & & 3.731 & .000 \\
\hline & .218 & .066 & .367 & 3.305 & .001 \\
\hline & & & & & \\
\hline & .176 & .106 & .159 & 1.657 & .101 \\
\hline & & & & & \\
\hline & .284 & .112 & .255 & 2.541 & .013 \\
\hline & & & & & \\
\hline & .085 & .069 & .107 & 1.233 & .220 \\
\hline & & & & & \\
\hline
\end{tabular}

a. Dependent Variable: TOTAL_Y

Source: Data Processed, 2019

From the table above we get the results of $t$ test for customer orientation variable (X1) showing a significance value of $0.001<5 \%$ which means $\mathrm{H} 1$ is accepted. Customer orientation has a positive influence on business performance with a coefficient of 0.218 . The result indicates that the higher customer orientation by SMEs by understanding the buyer's value chain will increase the value of customer satisfaction and produce good business performance.

T-test results for the competitor orientation variable $(\mathrm{X} 2)$ show a significance value of $0.101>5 \%$, which means $\mathrm{H} 2$ is rejected. Competitor orientation has no influence on business performance. This can be caused by MSEs which emphasize the focus on competition alone will ignore the interests of customers so that it does not affect business performance.

T-test results for the variable coordination between functions (X3) showed a significance value of 0.013 $<5 \%$, which means $\mathrm{H} 3$ is accepted. Coordination between functions has a positive effect on business performance of 0.284 . Coordination between functions is included in the market orientation component by combining functions to meet customer interests and satisfaction and win the competition. If the two functions run well, it will improve the MSME business performance.

T-test results for the innovation variable (X4) showed a significance value of $0.220>5 \%$ which means that $\mathrm{H} 4$ was rejected. Innovation without being balanced with good management will not improve business performance. 
Darroch, J. (2005). Knowledge management, innovation and firm performance. Journal of knowledge management, 9(3): 101-115.

Deshpandé, R., \& Farley, J. U. (1996). Understanding market orientation: a prospectively designed metaanalysis of three market orientation scales. na.

Ferdinand, A. (2006). Metode Penelitian Manajemen: Pedoman Penelitian untuk Skripsi, Tesis, dan Disertasi IImu Manajemen, Semarang: Universitas Diponegoro.

Ferdinand, A. (2004). Strategic Selling in Management. Research paper series. Seri Penelitian Manajemen No, 3.

Ferdinand, A. (1999). Strategy Pathways towards Sustainable Competitive Advantage. DBA Thesis. Southern Cross University, Australia.

Han, J. K., Kim, N., \& Srivastava, R. K. (1998). Market orientation and organizational performance: is innovation a missing link?. Journal of marketing, 62(4), 30-45.

Julian, C. C. (2010). The market orientation-marketing performance relationship-the empirical link in international joint ventures. International Journal of Trade and Global Markets, 3(4), 414-431.

Keskin, H. (2006). Market orientation, learning orientation, and innovation capabilities in SMEs. European Journal of Innovation Management, 9(4): 396-417.

Jaworski, B. J., \& Kohli, A. K. (1993). Market orientation: antecedents and consequences. Journal of marketing, 57(3), 53-70.

Kohli, A. K., \& Jaworski, B. J. (1990). Market orientation: the construct, research propositions, and managerial implications. Journal of marketing, 54(2), 1-18.

Narver, J. C., \& Slater, S. F. (1990). The effect of a market orientation on business profitability. Journal of marketing, 54(4), 20-35.

Pelham, A. M. (1997). Mediating influences on the relationsmp between market orientation and profitability in small industrial firms. Journal of Marketing Theory and Practice, 5(3), 55-76.

Putranto, S. E. (2003). Studi Mengenai Orientasi Strategi dan Kinerja Pemasaran. Jurnal Sains Pemasaran Indonesia (Indonesian Journal of Marketing Science), 2(1), 93-110.

Selnes, F., Jaworski, B. J., \& Kohli, A. K. (1996). Market orientation in United States and Scandinavian companies. A cross-cultural study. Scandinavian journal of management, 12(2), 139-157.

Sismanto, A. (2006). Analisis Pengaruh Orientasi Pembelajaran, Orientasi Pasar Dan Inovasi Terhadap Keunggulan Bersaing Untuk Meningkatkan Kinerja Pemasaran (Studi Empiris Pada Industri Kecil dan menengah Produk Makanan di Propinsi Bengkulu). Doctoral dissertation. Pascasarjana Universitas Diponegoro.

Sugiyono. (2009). Metode Penelitian Kuantitatif, Kualitatif dan R\&D, Bandung: Alfabeta.

Tjiptono, F., Chandra, G., \& Adriana, D. (2012). Pemasaran Strategik, Yogyakarta: CV. Andi offset. 